\title{
POESÍA JUDEOESPAÑOLA ADMONITIVA: CONCORDANCIAS ESTILISTICAS Y TEMÁTICAS CON LA LITERATURA MORAL CASTELLANA MEDIEVAL
}

\author{
CARMEN VALENTÍN \\ Grinnell College
}

\section{LAS COPLAS SEFARDÍES}

Las coplas son consideradas como el género poético sefardí más genuino y castizo. Elena Romero indica que

las coplas, si bien enraizadas en la coplística medieval española, son sin embargo, por su temática y por su función, una creación propia y singular del grupo: las han escrito los propios sefardíes para su propio consumo, buscando sus temas de inspiración en su propio sustrato cultural religioso como judíos o en sus propias vivencias históricas y cotidianas 1 .

Junto a esta indiscutible originalidad, varios estudios sobre el género han venido apuntando ciertas influencias o paralelismos con la creación literaria medieval (pan)hispánica. Así, José Manuel Pedrosa, al comparar las coplas sefardíes con los pliegos de cordel hispánicos, da evidencia de ese "enraizamiento" con la coplística medieval española mencionado en la cita de Romero y afirma que "no hay duda [...] de que las coplas españolas han proporcionado a las sefardíes el nombre y algunos elementos genéricos básicos [...]". Señala que la influencia formal y funcional es más general que la habida desde el romance y la canción hispánica hacia los correspondientes géneros sefardíes, pero que existe a tenor de la coincidencia de su denominación,

en el formato editorial típico del pliego o pequeño folleto, en la naturaleza fundamentalmente narrativa, en los recursos propios de la escritura, en el es-

${ }^{1}$ Elena Romero, La creación literaria en lengua sefardl, Madrid, Mapfre, 1992; cita en págs. 141-142 [en adelante, Romero, Creación]. Vid. también de la misma autora, "Las coplas sefardíes: Categorías y estado de la cuestion", Actas de las Jomadas de Estudios Sefardies, Cáceres, Universidad de Extremadura, 1981, págs. 69-98.

RFE, LXXXV, 2005, 2. ${ }^{\circ}$, pags. 295-320 
tilo artificioso, en la función cantable, en recursos formales tan característicos como la estrofa, la rima o el uso del acróstico, en determinados contenidos ideológicos y morales, en funciones y temas comunes como el noticierismo o las catastrofes naturales $[. . .]^{2}$.

Por otro lado, Iacob M. Hassán ha señalado que las coplas "cumplen una función equiparable a la que cumple la balada en la poesía de otros pueblos" 3 . Matiza que esta rama de la poesía sefardí no está integrada dentro de la baladística internacional por la ausencia del elemento de oralidad total de los textos, pero afirma que sí es equiparable con ella por lo que ambas comparten de poesía nacional. Hassán apunta los rasgos baládicos que se perciben en las coplas: "el cantar a héroes y mitos nacionales" o "hacer uso de elementos que forman parte del saber tradicional y específico de la colectividad", "el proceso de olvido del nombre del autor en el curso de la transmisión textual de aquellas coplas cuya autoría está identificada" y "el aprovechamiento de elementos textuales precedentes". Junto a esto, también menciona las características que las coplas comparten con la "otra gran corriente de la poesía internacional": la juglaría. Los recursos estilísticos que revelan la presencia física de un auditorio, el tratamiento dado a los diálogos, el procedimiento de la contrahechura, la intención de comunicar hechos o motivos que son de interés para toda la colectividad y la finalidad didáctica de ilustrar a las gentes de pocos conocimientos se aprecia de igual modo en las poesías sefardí y juglaresca.

Por último, Paloma Díaz-Mas asegura, tras examinar los poemas hispanojudíos escritos en lengua romance en la Edad Media: Proverbios morales (Sem Tob Ardutiel, siglo XIV), Coplas de Yoçef (anónimo, siglo XIV), El pecado original (anónimo, finales del siglo XIV) y Lamentación del alma ante la muerte (anónimo, anterior al siglo XV, probablemente de la primera mitad del XIV), que las coplas sefardíes son "un resurgimiento de esa poesía de clerecta rabtnica que se cultivó en la península probablemente desde el siglo Xm". Denomina clerecía rabínica a ese grupo de

autores cultos de formación rabínica, que utilizaban fuentes árabes y hebreas (seguramente además de otras cristianas), [y que escribieron una poesía] con unos rasgos formales peculiares de herencia semítica (irma silábica, estrofa zejelesca desde fechas muy tempranas, acróstico), que se difundio entre cristianos y judíos y que, entre éstos, fue usada con frecuencia como poesía litúrgica o paralitúrgica ${ }^{4}$.

\footnotetext{
2 José Manuel Pedrosa, "Coplas sefardíes y pliegos de cordel hispánicos", Sefarad, LV, 2, 1995, págs. 335-357; citas en págs. 357 y 356.

${ }^{3}$ Iacob M. Hassán, "Un género castizo sefardí: Las Coplas", Los sefardtes: Cultura y Literatura, San Sebastián, Universidad del País Vasco, 1987, págs. 103-117; cita en pág. 114. Vid. también Romero, Creación, págs. 158-162.

${ }^{4}$ Paloma Díaz-Mas, "Un género casi perdido de la poesía castellana medieval: La clerecía rabínica", BRAE, LXXIII, cuadeno CCLIX, 1993, págs. 329-346; citas en págs. 343 y 341 [en
} 
En las coplas que surgen en el siglo XVIII en el Imperio Otomano se reconocen iguales recursos formales y similar temática, siendo un gran número de ellas usado por el pueblo judío en sus celebraciones religiosas.

\section{LAS COPLAS DE CONTENIDO ADMONTTIVO}

Al leer la poesía judeoespañola de admonición ${ }^{5}$, uno de los subgéneros más relevantes de la coplística sefardí, se reconocen, por supuesto, varios de los rasgos hasta aquí expuestos: poemas transmitidos principalmente por vía libresca, en ediciones aljamiadas, y denominados por sus autores o editores como "co(m/n)plas", que, a nivel formal, tienen una extensión variable, muchos de ellos de veintidós estrofas al venir determinado este número por el acróstico que constituye el alefato hebreo, escritos en su mayoría siguiendo el esquema zejelesco (sin estribillo, como Lamentación del alma ante la muerte) y en los que la rima homoioteleuton es la segunda en frecuencia tras la consonante castellana. La regularidad silábica es notable en las coplas de contenido moral. En general, el anisosilabismo es escaso, salvándose la hipermetría con el uso de la sinalefa y, de modo más puntual, de la sinéresis y la apócope y la hipometría con el recurso de la diéresis. Si bien, la dialefa se muestra como general al conjunto del corpus: el número de veces en el que está presente en

adelante, Díaz-Mas, "Clerecía"]. Vid. también Díaz-Mas, "Poesía medieval judía", Judios en la literatura espaftola, Cuenca, Ediciones de la Unjversidad de Castilla-La Mancha, 2001, págs. 2955 [en adelante, Diaz-Mas, "Poesía"]; y de la misma autora y Carlos Mota (eds.), Proverbios morales, Madrid, Cátedra, 1998, págs. 86-92 [en adelante, Draz-Mas y Mota, Proverbios]. Remito a estos trabajos para la bibliografía esencial sobre estos poemas hispanojudíos.

5 Elena Romero y Leonor Carracedo, "Poesía judeoespañola admonitiva", Sefarad, 37, 1977, págs. 429-451. En este artículo, definen esta poesía como "aquella cuyo propósito es el de apartar al hombre del mal camino, criticando sus malas costumbres, para llevarie a la práctica de las virtudes". Romero, Seis coplas sefardies de "castiguerio" de .Hayim Yom-Tob Magula, con la colaboración de Carmen Valentín, Madrid, CSIC, 2003 [en adelante, Romero, Seis]; y "La última jornada del hombre en una copla sefardí de moral", Estudios Sefardíes, 3, 1980, págs. 403413 [en adelante, Romero, "Última"]. Vid. también Valentín, Edición y estudio de coplas sefardies zejelescas de admonición. Tesis, Univ. de Valladolid, 2002; y "Los extremos de la vida y sus conexiones con el poema judio medieval Lamentación del alma ante la muerte", Jewish Studies at the Turn of the $20^{\text {th }}$ Century. Proceedings of the $6^{\text {th }}$ EAJS Congress, vol. 2, Leiden, Brill, 1999, págs. 667-676. El corpus lo constituyen diecinueve coplas, de las que doy, a continuación, e] título y el año de la edición aljamiada impresa más antigua conservada según se lista en Elena Romero, Bibliografia analítica de ediciones de coplas sefardies, Madrid, CSIC, 1992; y Seis: Las malas costumbres (1739), Los extremos de la vida (1739), Visiones divinas (1739), El mundo al revés (1787), Un mundo nuevo (1787), Las edades del hombre (1787), Los pecados del hombre (1830), Contra los soberbios (1839), El buen obrar (1853), Azote de impios (1858), La última jomada (1858), Diálogo entre la Ley y el hombre (1858), Los pesares del alma (1861), Diálogo entre Dios y la nación (1869), Vanidad de las riquezas (1876), Tras el fuego de 1890 (1891), Por la senda del Criador (1896), Tras el pedrisco de 1899 (1899) y Tras las desgracias de 1913 (1913). 
los encuentros vocálicos es muy superior al de los resueltos con sinalefa; como ejemplo sirvan estas estrofas de Las malas costumbres (ests. 133-136):

\author{
que esto es telaraña, \\ toda esta habla vana; \\ hablar en estas patrañas \\ es pecado en semana, \\ cuánto más en este día \\ que de el Dio es bendicho, \\ lo dio a la judería \\ que afirmemos su dicho \\ y que no lo eśviblemos \\ ni con habla ni con hecho, \\ aviciándolo ternemos \\ la heredad sin estrecho. \\ $Y$ tenemos de uśar \\ comer, beber y meldar \\ y un poco repośar; \\ sienpre a este andar ${ }^{6}$.
}

La regla del hiato parece que estuvo activa entre los poetas de la "clerecía rabínica"7 según se ha demostrado para los Proverbios morales - los cuales

${ }^{6}$ Transcribiré el texto aljamiado y los hebraísmos siguiendo el sistema propuesto por Iacob M. Hassán, "Transcripción normalizada de textos judecespañoles", Estudios Sefardíes, 1, 1978, págs. 147-150. Siempre que ejemplifique con las coplas Las malas costumbres, Los extremos de la vida, Visiones divinas, El mundo al revés, Un mundo nuevo y Las edades del hombre, reproduciré el texto según transliteración de Romero, Seis; y, para La última jornada, de Romero, "Última".

${ }^{7}$ Seguramente influidos por los autores del mester de clerecía, para quienes Ia regla del hiato fue práctica habitual durante el siglo XII (en el XIV se le empezó a dar cierto margen a la sinalefa). No sabemos si los copleros sefardíes estaban pensando en la perfecta escansión de sus poemas al mencionar su buen hacer poético en estrofas como las que siguen de El mundo al revés (est. 1) y Tras el fuego de 1890 (est. 1):
Esta cantiga por mí está hecha
bien asentada y bien derecha;
llarnalda cantiga o llamalda endecha.
Oid hermanos en este cante,
que yo lo asentí y con mucho arte
por que tome moral y de el Dio se espante
y en el judeśmo siempre vaya avante.

Pero ellas sí traen a la mente la segunda del Libro de Alexandre [cito de Francisco Marcos Marín (ed.), Libro de Alexandre, Madrid, Alianza Editorial, 1987, pág. 91 (en adelante, Marcos Marín, Libro)]: 
están escritos en "un alejandrino bastante estrictamente construido" 8 y en ellos "rige siempre el principio de la dialefa" - y Lamentación del alma ante la muerte -cuyo editor cree en la regularidad heptasilábica de la composición aunque en su edición crítica no pueden ser corregidos de modo satisfactorio cinco versos, lo que para él "es una proporción que no es decisiva si se tiene en cuenta el pésimo estado de la transmisión del texto" y afirma que "el poeta aplicaba rigurosamente la ley del hiato en los encuentros vocálicos dentro del verso" ${ }^{10}$ - Por otro lado, Gómez Moreno indica al hablar de El pecado original que "consta de 51 versos en cuartetas y otras estrofas (algún que otro dístico y trístico) monorrimas de métrica diversa, aunque predominan los versos de once y doce sílabas. [...] los tetrásticos monorrimos se aferraron en otros países a metros distintos del $7+7$ desde época muy temprana. En este caso, el poeta debió de tener como base $6+6$, permitiendo - quizás por torpeza- ligeras oscilaciones; sin embargo, una vez más es lícito suponer que el paso del tiempo puede haber jugado un papel importante en dichos cambios, pues la única copia conservada es de la primera mitad del siglo $\mathrm{Xv}{ }^{11}$. Aunque la es-

$$
\begin{aligned}
& \text { Mester traygo fermoso non es de ioglaria } \\
& \text { mester es sin pecado que es de clerezia } \\
& \text { fablar curso rimado por la quadern[a] [u]ia } \\
& \text { a silauas contadas que es grant maestria }
\end{aligned}
$$

con ecos en otras obras posteriores, como el Libro de Buen Amor, en la que el verso dos declara la rectitud formal y moral del texto [vid. Raimond Willis, "Mester de clerecia. A Definition of the $L i$ bro de Alexandre", Romance Philology, 10, 1956-1957, págs. 212-224; Carlos Alvar y Ángel Gómez Moreno, La poesia épica y de clerecia medievales, Madrid, Tauns, 1988, págs. 157-163 (en adelante, Alvar y Gómez Moreno, Poesía); Gómez Moreno, "Notas al prólogo del Libro de Alexandre", Revista de Literatura, 46, 1984, págs. 117-127 (en adelante, Gómez Moreno, "Notas")].

${ }^{8}$ Díaz-Mas y Mota, Proverbios, pág. 43. La estrofa de las Coplas de Yoçef ha sido calificada de cuaderna vía anómala ya que "los versos son mayoritariamente alejandrinos (con algún fallo fácilmente subsanable en una edición crítica) y se agrupan en estrofas de cuatro. Aunque las rimas no coinciden con las de la cuaderna vía del mester de clerecía, sino que introducen un elemento de la poesía semítica, como es la rima zejelesca [...]", en Díaz-Mas, "Poesía", pág. 36.

9 Isabel Uría Maqua, "Los Proverbios morales de Sem Tob de Carrión y su relación con el Mester de Clerecta", Las Tres Culturas de la Corona de Castilla y los Sefardies, Salamanca, Junta de Castilla y León, 1990, págs. 31-47; cita en pág. 36. Ella apoya la afirmación de Agustín Garcia Calvo, (ed.) en Don Sem Tob, Glosas de Sabiduria o Proverbios Morales y otras Rimas, Madrid, Alianza, 1983, $2^{2}$ ed. Vid. también de la misma autora, "Algunos aspectos de ta versificación y el estilo de los Proverbios morales de Sem Tob de Carión", El Olivo, XIII, 1989, págs. 281-290.

10 Jesús A. Cid, "Lamentación del alma ante la muerte: Un nuevo poema medieval judeoespañol", Poesía estrófica: Actas del I Congreso Internacional sobre Poesía Estrófica Árabe y Hebrea y sus Paralelos Romances, Madrid, Universidad Complutense-Instituto de Cooperación. con el Mundo Árabe, 1991, págs. 43-70; cita en pág. 59.

"Alvar y Gómez Moreno, Poesía, pág. 127. También señala que la "cuaderna vía sirvió como medio de expresión para otros muchos autores pertenecientes a las religiones musulmana o judía que sentian la necesidad de exponer las normas de conducta de sus respectivas creencias, acorde generalmente a las cristinas.", pág. 130. 
trofa predominante en el corpus admonitivo es la de esquema zejelesco, cuatro de las coplas están escritas con cuartetos monorrimos de tendencia dodecasilábica (son estos poemas los que más irregularidades métricas presentan).

A nivel temático, su misión es castigar y adoctrinar al hombre para que abandone el mal y viva dentro de los principios de Dios y la religión judía, por ello los motivos sobre los que gira el discurso admonitivo son el mal -se detallan los pecados y vicios en los que el hombre va perdido y las desgracias a las que dan lugar-, el bien - se llama al arrepentimiento y se enumeran los preceptos y deberes que el hombre debe cumplir para gozar del cobijo de Dios-y la muerte -acechante y desoladora, es la única verdad con la que el hombre debe contar-, los cuales se reconocen en los poemas morales hispanojudíos (todos los citados arriba excepto Coplas de Yoçef) al ser tópicos de la poesía penitencial judía. Asimismo, ciertas coplas hacen referencia o nacen a partir de una determinada catástrofe (fuego, pedrisco), aunque en ellas no se hace una descripción detallada del hecho (que sí se encuentra en las coplas de tema noticiero). La finalidad didáctica está en el origen del género coplístico, y por tanto de las coplas admonitivas, al nacer con la misión de presentar en judeoespañol leyendas, doctrinas, leyes y reglas de comportamiento tradicionalmente escritas en hebreo, lengua que la mayoría de los sefardíes no podía entender a principios del siglo XVII. Mención a este hecho se hace en la copla Un mundo nuevo (est. 13):

$$
\begin{aligned}
& \text { No me lo toméš a manco, } \\
& \text { me estimés por un cavaco } \\
& \text { que hiće cantiga en franco } \\
& \text { para que entiendan el mundo }{ }^{12} \text {. }
\end{aligned}
$$

donde la expresión "en franco" se refiere a la lengua en la que está escrita. Para elaborar su discurso, los copleros correctores de costumbres se valen (al igual que en El pecado original, Coplas de Yoçef y pasajes de Proverbios) de referencias a la Biblia, al Midrás y al Talmud y a motivos y personajes presentes en el saber religioso de la comunidad como, por ejemplo, los padres de la nación (Abraham, Isaac y Jacob), Esaú (hermano de Jacob y representante del pueblo crístiano) o el templo de Jerusalén. Los poetas hacían asimismo uso de elementos textuales previamente empleados por otros copleros sin sentir que estaban cometiendo plagio. Por lo tanto, se pueden encontrar coplas casi idénticas entre sí, en las que la única diferencia, o la más destacable, entre la original y sus "copias" es la ausencia en estas últimas de las estrofas finales que declaraban, a través del acróstico onomástico, el nombre del autor. Tal hecho es, además, un ejemplo de la poca importancia que se daba a la identidad del

12 tomés a manco: 'toméis en falta'; cavaco: 'bobo'. 
poeta. Algunas coplas de castiguerio, aunque no habían nacido con una finalidad (para)litúrgica, eran recitadas en ciertas celebraciones del calendario judío debido a su contenido, tales como los días dedicados al arrepentimiento (al igual que Lamentación del alma ante la muerte ${ }^{13}$ ) o el día que precede a la circuncisión de un niño.

\section{RECURSOS Y TEMAS COMUNES CON LA LITERATURA MORAL CASTELLANA ME- DIEVAL}

Junto a todos estos elementos, en la poesía judeoespañola admonitiva, se reconocen asimismo recursos y temas propios de la literatura de igual contenido: la didáctico-moralizante, que se escribió en castellano durante la Edad Media en la península dentro de la tradición cristiana, la cual presenta también puntos comunes con la cultivada por los. poetas hispanojudíos.

\section{Recursos}

Porque la misión de la poesía admonitiva es alertar al hombre del mal que comete y conducirle al arrepentimiento, la penitencia y la corrección de costumbres al tiempo que se le recuerdan cuáles son las prácticas religiosas y principios éticos del judá́smo que debe cumplir para vivir bajo la protección de Dios, la labor de los copleros recuerda en gran medida la realizada por los predicadores en la Edad Media, la cual queda descrita por un predicador de la época en el siguiente fragmento citado por Pedro Cátedra:

Fablando generalmente todo predicador deve aver quatro clamores: el primero deve ser para despertar e abivar; el segundo, para amonestar e enduzir; el terçero, para amenazar e espantar; el quarto, para consolar e falagar. Digo lo primero que deve el predicador abivar e despertar el coraçón del peccador non con palabras afeytadas nin de burlas que lo provoquen al riso, más, segúnd dicho es, con palabras quel pongan temor en el coraçón, en manera que lo abiven para bien fazer... ${ }^{14}$

13 "[...] todo parece indicar que al menos algunos de estos poemas tuvieron entre los judíos medievales un uso paralitúrgico, [...] el tema de José es propio de la festividad de Purim, [...]; et Pecado original se cantó hasta fechas recientes en Tǐs’á beab; la Lamentación del alma ante la muerte parece un poema penitencial para yamim nora' im, e incluso no es imposible que a algunos pasajes de los Proverbios morales les diesen sus lectores judios un uso similar", Díaz-Mas y Mota, Proverbios, pág. 89.

14 Pedro Cátedra, Los sermones atribuidos a Pedro Marín: van añadidas algunas notas sobre la predicación castellana de san Vicente Ferrer, Salamanca, Universidad de Salamanca, 1990, pág. 78 [en adelante, Cátedra, Sermones]. Fragmento del Ms. 1854, fols. 60-61, conșervado en la Biblioteca Universitaria de Salamanca. 
Los poetas sefardíes llevaron a cabo esta tarea con rigor. Para el coplero, es importante poner especial cuidado en anunciar la intención moralizante de sus poemas. Es general al corpus admonitivo encontrar una(s) estrofa(s) de introducción que sirve(n) para llamar la atención sobre el contenido moral de la composición y hacer reflexionar sobre el terna que se va a desarrollar a continuación, como se aprecia en las dos primeras estrofas de la copla Visiones divinas:

$\begin{array}{ll}\begin{array}{l}\text { Escuchad señores, } \\ \text { comé de este pan } \\ \text { sentid mis palabras }\end{array} & \begin{array}{l}\text { oyid lo que digo: } \\ \text { que es de buen trigo, } \\ \text { son palabras justas }\end{array} \\ \begin{array}{l}\text { que son de amigo } \\ \text { con temor del Dio }\end{array} \\ \begin{array}{l}\text { Abrid vuestros ojos } \\ \text { despertá, porque }\end{array} & \text { y vuestros sentidos, } \\ \text { mirá, mis hermanos, } & \text { estás adormecidos; } \\ \text { por muestros pecados } & \text { que estamos perdidos: } \\ \text { mos castiga el Dio. }\end{array}$

La misma llamada de atención sobre el contenido moral de la obra se lee en los Proverbios morales de Sem Tob, en este caso apelando a un único oyente, el rey Pedro I de Castilla, a quien está dedicada la composición:
Señor rey, noble, alto, que viene dezir Santo,
oí este sermón comunalment trobado, judío de Carrión, de filosofía sacado, de glosas moralmente segunt aquí va siguiente ${ }^{16}$.

y ello parece ser costumbre en la poesía narrativa medieval ${ }^{17}$, como ejemplifica la estrofa que inicia el Libro de miseria d'omne:

\footnotetext{
15 Esta estrofa nos remite a un tópico de las fórmulas de introducción de la literatura moralizante medieval [vid. Jacques Joset (ed.), Libro de Buen Amor, Madrid, Espasa-Calpe, 1974, pág. 16]: considerar estas composiciones como solaz del alma. Así aparece en el Libro de Alexandre o en el Libro de Buen Amor, del que cito su estrofa 14:

$\mathrm{Si}$ queredes, señores, oír un buen solaz, ascuchad el romançe, sosegadvos en paz; non vos diré mentira en quanto en él yaz, ca por todo el mundo se usa e se faz.

Asimismo, en el v. 2a de Visiones Divinas, se lee otro tópico medieval: "pan de trigo", al que Díaz-Mas ["Poesía", pág. 37] hace referencia al hablar del poema hispanojudío El pecado original [cito del mismo artículo, pág. 46]:

Díxole asy: "Muger, vete comigo

a un árbol donde ay tanto buen figo:

comeremos averme as por amigo,

e saberás quál es el pan de trigo.

el cual se recoge en Berceo en varios pasajes de Milagros de Nuestra Señora.

${ }^{16}$ Díaz-Mas y Mota, Proverbios, pág. 119.

${ }^{17}$ Alvar y Górnez Moreno, Poesía.
} 
Todos los que vos preciades más vos preciaredes siempre el que bien lo retoviere sabrá dexar abolezas venit a seer comigo;

si oyerdes lo que digo;

a Dios abrá por amigo, muchas que trae consigo ${ }^{18}$.

Igualmente, los sermones comenzaban con una frase o sentencia bíblica en latín que constituía el thema, que, generalmente ya en romance, era explicado en la introductio thematis antes de ser desarrollado, la cual venía asociada a "la necesidad de preparar a los oyentes" 19.

El coplero también siente la necesidad de ensalzar el contenido didácticomoralizante de su obra en contraste con esas otras composiciones que no enseñan nada al hombre y que sólo le sirven de pasatiempo. La estrofa 12 de Visiones divinas dice:

$$
\begin{array}{ll}
\text { Yo hago cantigas } & \text { que los hombres canten, } \\
\text { vean mis palabras } & \text { y que se quebranten; } \\
\text { no hago cantigas } & \text { que bailen y salten, } \\
\text { que en nada de esto } & \text { no envelunta el Dio }
\end{array}
$$

Estas palabras nos recuerdan de nuevo la estrofa segunda del Libro de Alexandre ${ }^{21}$. Sin embargo, afirmaciones similares, en las que se condenaban las actividades y composiciones destinadas al divertimiento en favor de las que doctrinan, son hechas en textos como la Glosa al Pater Noster, supuestamente escrita por san Pedro Pascual:

amigos, creer que mejor despenderedes vuestros días y vuestro tiempo en leer e oír este libro que en dezir e oýr fablillas y romances de amor y de otras vanidades 22 .

así como en actas de sínodos y concilios en la España medieval y en el Libro de las confesiones de Martín Pérez, según se lee en este fragmento del Sínodo de Cuéllar de 1325:

Otrosí, los clérigos non deven husar de joglarias nin de alvardanes [...] Otrosí, en las iglesias non se deven fazer juegos sinon si sean juegos de las fiestas así commo de las Marías e del monumento, pero an de catar los clérigos que por tales juegos non trayan el divinal ofiçio ${ }^{23}$.

${ }^{18}$ Reproduzco el texto de Jane E. Connolly, Translation and Poetization in the Quadema Via: Study and Edition of the "Libro de miseria d'omne", Madison, The Hispanic Seminary of Medieval Studies, 1987, pá. 121 [en adelante, Connolly, Translation].

19 Pedro Cátedra, Los sermones en romance del manuscrito 40 (siglo xv) de la Real Colegiata de San Isidoro de León, Salamanca, Seminario de Estudios Medievales y Renacentistas, 2002, pág. 37 [en adelante, Cátedra, Manuscrito].

20 envelunta: 'se complace'.

21 Cfr. nota 7.

${ }^{22}$ Gómez Moreno, "Notas", pág. 125; Alvar y Gómez Moreno, Poesía, pág. 163.

${ }^{23}$ Ángel Gơmez Moreno, El teatro medieval castellano en su marco románico, Madrid, Taurus, 1991; cita en pág. 64. Este párrafo está recogido de José Lujs Martín y Antonio Linage Conde, Catecismo de Pedro de Cuéllar, Salarnanca, Junta de Castilla y León, 1987. 
Sin embargo, parece que esta labor doctrinadora no siempre era bien acogida por el público ya que son varias las ocasiones en las que los copleros ofrecen sus excusas o temores por que sus palabras puedan no ser del gusto de todos. La copla El mundo al revés tiene como tema el lamento del poeta por la incomprensión de las gentes de su oficio y en otras se leen estrofas similares a ésta de La última jornada (est. 1):

$$
\begin{array}{lc}
\text { Muncho mejor era } & \begin{array}{c}
\text { de estar callado } \\
\text { no salga alguno }
\end{array} \\
\text { que esté ensañado: } \\
\text { "A vos no vos caye } & \text { de tener cudiado". } \\
\begin{array}{l}
\text { Qué haré, nišgüelo, } \\
\text { que so muy celośo, }
\end{array} & \begin{array}{l}
\text { en el corazón } \\
\text { estó doloriośo }{ }^{24} \text {. }
\end{array}
\end{array}
$$

Para llegar a la conciencia pecadora y conquistarla ${ }^{25}$, al igual que los predicadores medievales, el poeta sefardí se implica sobre manera en su composición para dirigirse a un público con el que habla, al que apela, interpela y da voz, rasgo que, asimismo, revela la presencia física de un auditorio. Estos elementos ya han sido señalados como comunes de la coplística sefardí con la comiente juglaresca, pero no son exclusivos de ésta al percibirse también en la obra literaria de los clérigos medievales, y no meramente limitada a los sermones ${ }^{26}$. Desde el comienzo de los poemas admonitivos, el autor se manifiesta como un yo individual ("Escuchad señores, oyid to que digo:" ${ }^{27}$ ) o como un nosotros colectivo ("Ód hermanos queridos: / ¿hasta cuándo vamos acoridos" ${ }^{28}$ ), como el narrador de la composición. Con ello, parece existir una intención del coplero de centrar la atención del oyente no sólo en lo que va a ser

${ }^{24}$ Romero, "Última", págs. 404-405, la explica como: "Mejor sería permanecer callado, ya que puede venir algún colérico a decirme: No es cosa tuya preocuparte de estos asuntos; pero, pobre de mí (nišgüelo), no tengo más remedio que hablar, ya que mi celo y mi corazón dolorido me impiden callarme."

${ }^{25}$ Francisco Rico, Predicación y literatura en la España medieval, Cádiz, UNED, 1977 [en adelante, Rico, Predicación]; Alan Deyermond, "The Sermon and its Uses in Medieval Castilian Literature", La Corónica, 8, 1980, pags. 127-145 [en adelante, Deyernnond, "Sermon"]; Francisco Javier Fernández Conde, "La transmisión del saber en una sociedad predominantemente analfabeta: Una catequesis permanente al servicio de una cosmovisión cristiana", Historia de España Menéndez Pidal: La época del gótico en la cultura española, vol. 16,-Madrid, Espasa Calpe, 1994, págs. 861-890; Pedro Cátedra, Sermón, sociedad y literatura en la Edad Media. San Vicente Ferrer en Castilla (1411-1412): Estudio bibliografico, literario y edición de los textos inéditos, Salamanca, Junta de Castilla y León, 1994 [en adelante, Cátedra, Sermón]; Sermones y Manuscrito.

${ }^{26}$ Para influencias del sermón en otros géneros literarios medievales, vid. Rico, Predicación y Deyermond, "Sermon". Para rasgos juglarescos en la poesía de clerecía, vid. Alvar y Gómez Moreno, Poeśa; y Gómez Moreno, "Proyección de la cultura oral sobre la vida. La transmisión oral del saber: juglares, épica y teatro", Historia de España Menéndez Pidal: La época del gotico en la cultura española, cit., págs. 830-860.

${ }^{27}$ Visiones divinas (v. 1a).

28 Por la senda del Criador (vs. 1ab). 
comunicado, sino también en quien lo comunica, ya que él, con su voz y mensaje, se convierte en el vehículo para llevar la palabra de Dios a los oyentes y, por lo tanto, en el principal artífice de la conversión moral de su público. Como el predicador, el coplero "se erige en vigilante y despierta con sus temores" ${ }^{29}$, como declara el autor de Las malas costumbres (ests. 3.4, 10):
Šalom 'alejem, señores,
el Dio esté en sus ayudas;
no erezcan sus fulores
si hablo palabras crudas ${ }^{30}$.
Que de lástima que siento
hablo muy desesperado;
hablaré uno por ciento
de lo que estó quemado.
Por tenerlos en memoria
este camino tomí
de haćer una historia
por mí y otros como mí.

Tras la introducción, no es frecuente que el poema continúe en primera persona singular, sino en primera plural, haciéndose la voz del coplero colectiva y mostrando de este modo tanto su parte de responsabilidad en los actos de pecado como de beneficio en los de arrepentimiento y recompensa. Sin embargo, no faltan ocasiones en las que, dentro de su discurso colectivo, el poeta se aísla y habla por sí mismo para lanzar un ruego, expresar una opinión o un pensamiento o entrometerse con comentarios a palabras puestas en boca de otros, segín se observa en las siguientes estrofas de Visiones divinas (est. 7) y Las edades del hombre (est. 6) :

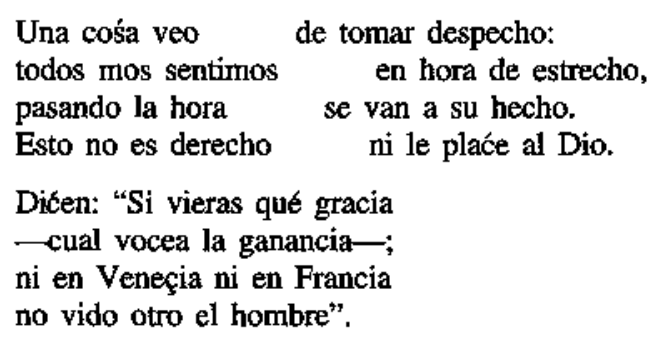

Es raro encontrar en las coplas admonitivas la autoacusación del poeta, como sí es recurso popular en los sermones, tal y como se aprecia en el titulado Sermón de los VII pecados mortales editado por Cátedra:

\footnotetext{
${ }^{29}$ Cátedra, Sermones, pág. 78.

30 Šalom 'alejem: Forma de salutación, lit. "la paz sea con vosotros'; no erezcan sus fulores: 'no os encolericéis'.
} 
Pues yo, que bivo çincuenta años en pecado, devo entender que he fecho muchos pecados ${ }^{31}$.

a no ser que, de modo indirecto, se trasluzca al excusarse por su admonición, según se aprecia en la estrofa que cierra la copla Las edades del hombre (est. 31):
No se arabien tan presto porque hable deshonesto; por mí digo todo esto, no hablo por dingún hombre.

Sin embargo, la ya mencionada Las malas costumbres se inicia con una confesión (11 estrofas) del coplero en la que, al tiempo que explica los porqués de su crítica a la falta de las prácticas y principios éticos del judaísmo que observa, se reconoce pecador, como se declara en la estrofa 9:

$$
\begin{aligned}
& \text { De pensar en mis pecados } \\
& \text { se me quema el corazon, } \\
& \text { los nuevos y los pasados } \\
& \text { no hay cuenta cuántos son. }
\end{aligned}
$$

El yo confesional se aprecia de igual modo en la estrofa 17 de los Proverbios morales de Sem Tob:

$$
\begin{array}{ll}
\text { Yo estando con cueita } & \text { por miedo de pecados } \\
\text { muchos que fiz, sin cuenta, } & \text { menudos e granados }
\end{array}
$$

Esta estrofa, junto a las siguientes hasta la 26, evoca los tópicos de la seliha ${ }^{33}$, la poesía penitencial para recitarse en los días de ayuno y penitencia del calendario judío. Una de sus modalidades es el viduy o 'confesión', género que Sem Tob cultivó en hebreo y al que pertenece Lamentación del alma ante la muerte. Pero estos poemas no son parte del género confesional ${ }^{34}$, por lo que introducir este tipo de fórmulas iniciales parece estar en concordancia con el uso

${ }^{31}$ Cátedra, Manuscrito, pág. 118. Sermón anónimo, el número 2 en la edición de Cátedra de los sermones del Códice $\mathbf{4 0}$ (siglo Xv) de la Real Colegiata de San Isidoro de León, con foliación $142(141) \mathrm{v}-143(142) \mathrm{v}$.

32 Díaz-Mas y Mota, Proverbios, pág. 124.

${ }^{33}$ Díaz-Mas, "Clerecia", pág. 333; y Jescís A. Cid, "Lamentación del alma ante la muerte. Nuevo poema medieval", Estudios de Folclore y Literatura dedicados a Mercedes Díaz Roig, México, El Colegio de México, 1992, págs. 729-791 [en adelante, Cid, "Lamentación"].

${ }^{34}$ Díaz-Mas y Mota, Proverbios, págs. 64-65. lacob Hassán indica al caracterizar el género coplístico que en f́l no suelen aparecer confesiones autobiograficas y que "To habitual es que el coplero, por personal que sea su tratamiento del tema, se exprese no como individuo sino como portavoz y que su creación pueda ser asumida por cada uno de los miembros de la comunidad"; cito de Elena Romero, Primera selección de coplas sefardíes, Cóndoba, El Almendro, 1991 págs. 17-18. 
tópico que de ellas se hacía en la poesía cristiana medieval, según demuestra Jacques Joset ${ }^{35}$ con ejemplos del Libro de Buen amor y del Rimado de Palacio, cito de este último su estrofa 17 :

Conosco yo, Señor, que nunca te serví

Como leal cristiano; en todo fallesçí,

E todo el mi tiempo muy mal lo despendí.

Por ende, me confieso luego, Señor, a tín ${ }^{36}$.

En cualquier caso, en su empeño de hacer triunfar su misión aleccionadora para que el hombre, como género humano, comprenda que su pecado es la causa de sus desgracias, el coplero sefardí juega con el empleo de las diferentes personas para conseguir la formulación que más efectivamente llegue a la conciencia del oyente y lo agite a la conversión: incluyéndose (yo, nosotros) o excluyéndose (tú, vosotros) de las acciones presentadas o llegando a abandonar las referencias directas al público o a él mismo para introducir la tercera persona impersonal, que sigue englobando a todos, coplero y audiencia, pero que sirve para que el poeta enfatice y el público reconozca que lo dicho aplica a todo ser humano, sin excepción. Así se revela en la siguiente estrofa de $L a$ última jornada (est. 5):

Vengamos a ver cabo de el hombre:
$\begin{aligned} & \text { de muncho que pena } \\ & \text { y que tanto core }\end{aligned}$
$\begin{array}{ll}\text { por fraguar palacios } & \text { y una gran tore } \\ \text { al cabo verés } & \text { se echa en cama, } \\ \text { por el médico } & \text { manda y lo llama. }\end{array}$

Si la presencia del coplero es clara desde el inicio de los poemas de admonición, no lo es menos la del público al que van dirigidos. Ya las primeras estrofas son una apelación a la audiencia, y en muchos casos también una invitación para que participe de la copla, como se lee en éstas de El buen obrar (ests. 1-2):
Oíd, mis hermanos, y el que la oye y él que mos quite de tantas fortunas Bendichos de el Dio,
en esta cantiga
a el Dio bendiga; de tanta fatiga, como la espiga. verid, vos hablaré

${ }^{35}$ Jacques Joset, "Pour une archéologie de l'autobiographie; de quelques modalités du yo dans les Proverbios morales de Sem Tob de Carrión", L'Autobiographie dans le monde hispanique: Actes du colloque intermational dela Baume Lès Aix, 11-12-13 mai 1979, Aix-en Provence, Publications de 1'Université de Provence, 1980, págs. 77-94; vid. también del mismo autor las ediciones del Rimado de Palacio, Madrid, Alhambra, 1982, y del Libro de Buen Amor.

${ }^{36}$ Reproduzco el texto de Kenneth Adams (ed.): Rimado de Palacio, Salamanca, Anaya, 1971, pág. 45. 


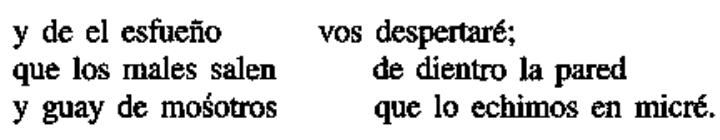

La admonición es lanzada siguiendo un tono directo y personal, lo cual se manifiesta con los recursos que persiguen la implicación de los oyentes: interpelaciones, preguntas que buscan la atención y la reflexión —unas parecen esperar una respuesta inmediata de la audiencia, otras vienen acompañadas de una advertencia, un comentario o la respuesta, que puede ser la correcta o no, ya refleje el pensamiento del coplero o el del público-, estilo directo para transmitir palabras o ideas cotidianas que el receptor puede reconocer como propias o, incluso, invitaciones que parecen llamar a la repetición en coro:

¡Hombre!, ¿en qué te contienes

que tanta sobrebia tienes?

Para mientes d'ánde vienes

y tu fin: polvo y tiera.

Los extremos de la vida (est. 2)

Si todo esto sabemos,

¿en qué mo lo contenemos?

Si en hacienda, diremos

no lo escapan al hombre.

Las edades del hombre (est. 29)

¿Cómo bušcaréš repośo,

alegría, gusto y goźo?

Su cabo es de cerar el ojo

$y$ pudrirse en la tiera.

Contra los soberbios (est. 16)

Šalom damos a la cara:

"La ropa mos costa cara".

Quita tanto por la tara

como uśanza de el mundo ${ }^{37}$.

Los pecados del hombre (est. 21)

El Dio de los cielos alto y enšalžado

mos mande ya muestrore y encoronado,

\footnotetext{
${ }^{37}$ La estrofa presenta el engaño al cliente, a quien se le saluda amablemente cuando llega a comprar (v. a), pero al que se le va diciendo sutilmente lo cara que cuesta la mercancía $(v, b)$ para justificar lo que se le va a robar (v, c).
} 


$$
\begin{aligned}
& \text { descubra su honra a todo el poblado } \\
& \text { y diremos todos: "Éste es muestro Dio". }
\end{aligned}
$$

Visiones divinas (est. 13)

Todos estos recursos que implican a emisor y receptor en la copla admonitiva se reconocen en los Proverbios morales ${ }^{38}$ :

$$
\begin{aligned}
& \text { Cobdiçia e derecho - Esto es cosa çierta- } \\
& \text { E fallo tres dolençias non pueden guareçer } \\
& \text { nin ha tales espeçias que las puedan vençer: [...] } \\
& \text { tu bien gran mal le faz, no.l teniendo tú tuerto: } \\
& \text { por bebir tú en paz se tiene él por muerto. } \\
& \text { ¿Qué más venga quesieste aver del embidioso } \\
& \text { más que estar él triste ' cuando tú estás gozoso? }{ }^{39}
\end{aligned}
$$

y, como ya anunciamos arriba, en la literatura cristiana, para la cual sirven de ejemplo estos pasajes de un poema de la Pasión de Cristo descubierto por Gómez Moreno en el manuscrito 9/5809 de la Real Academia de la Historia:
$E$ en persona fallando de cada vn omne mortal digo esta razón tal, mis amigos consejando: Omne, vayte castigando de no enojar a tu saluador, que por ty fue sofridor, segund te iré contando.
Recuérdate peccador, auiendo grand contrición, de la muerte e passyón que sufrió Nuestro Señor. Tú fueste merescedor déstos merescimientos porque de grandes tormentos Ihu. fue padescedor ${ }^{40}$.

del Libro de miseria d'omne:

¿O vil lodo e ceniza! ¿A Adam, por aventura, que del limo de la tierra Tú eres de semient d'omne,

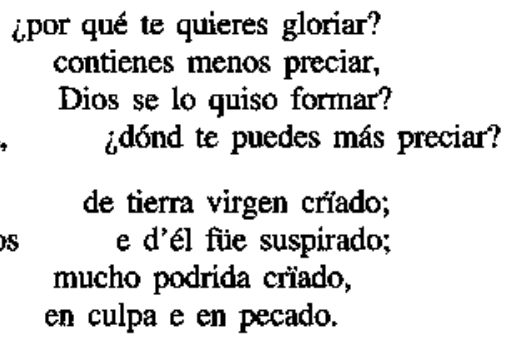

de tierra virgen crïado; e d'él füie suspirado; mucho podrida criado, en culpa e en pecado.

Cierto Adam fue, sepades, formólo Dios con sus manos tú de semiente de omne e demás fust concebido

\footnotetext{
${ }^{38}$ Según se expone en Díaz-Mas y Mota, Proverbios, pág. 65.

${ }^{39}$ Díaz-Mas y Mota, Proverbios, págs. 186-189.

40 Ángel Gómez Moreno, "Nuevas reliqujas de la cuaderna vía", Revista de Literatura Medieval, 2, 1990, págs. 9-34; cito de págs. 26-27.
} 


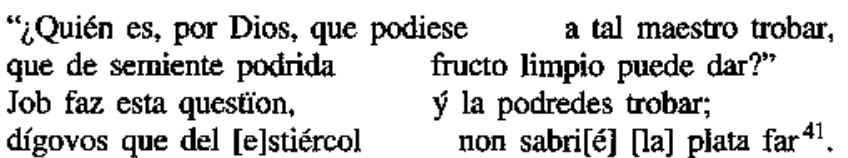

y este fragmento de un sermón de San Vicente Ferrer editado por Cátedra:

La segunda cosa que podemos e devemos confiosamente esperar en Dios es rremissión liberal. Esto es, que por pecadora que sea la criatura e que aya fechos quantos peccados ha en el mundo, si ha dolor e contriçión dellos e propone de nunca jamás tornar a ellos e los confiessa bien todos e cunple la penitençia que le da el confessor, digo que tal persona confiosamente deve esperar que Dios le dará rremisión e la perdonará. [...] Pues que assí es, tú, omne pecador e mugier peccadora, allégate a Dios, ca assí como el fuego tyra la teniebra de la noche e el frío que omne ha quando a él se allega, assý Dios te perdonará tus peccados si a Él te allegas.

¿E cómo te allegarás que por ventura estás apartado e allongado d'Él más de mill jornadas por la muchedunbre de los peccados que has fechos? Yo digo que te allegarás a Él con quatro jomadas o con quatro pasos solos. [...]

Agora, buena gent, catad aquí un secreto: así como Dios dava sanidat mandando e non le calía mogar, ca Él era Dios, agora declararemos este secreto: ¿quién es este paralítico e quién sson estos quatro que lo traen?, e assí veremos la remissión. $[\ldots]^{42}$

\section{Temas}

Los recursos hasta ahora vistos se revelan como fundamentales al combinarse y ser la vía de expresión de los motivos temáticos propios del género, ya que la habilidad al presentarlos juntos en el discurso admonitivo será la clave del éxito del coplero en su deseo pedagógico de crear un mensaje eficaz, al tiempo que directo y coloquial, que cale en todo tipo de público.

Al igual que los clérigos medievales, los poetas sefardíes sabían que "para instruir sobre las buenas costumbres, había que evocar también las malas; para dar reglas de conducta, había que ser muy concreto en la descripción de comportamientos y actitudes" ${ }^{43}$. Por ello, los poemas de admonición no pierden la ocasión de dar una visión exacta de cuáles eran las costumbres cotidianas y castigables del sefardí de la época: poca honradez de los comerciantes, nuevas modas y lujos de las mujeres, falso juramento, hipocresía, orgullo, codicia, mal

\footnotetext{
${ }^{41}$ Connolly, Transiation, págs. 123-124.

42 Cátedra, Sermón, págs. 341-342. Sermón "quizás predicado en Segovia o en alguna de sus villas con aljama judía importante, durante la semana que va del 30 de agosto al 5 de septiembre" de 1411. Su "thema, "Fiduciam talem habemus ad Deum" (2 Cor 3, 4) procede de la lectura propia del domingo doceno después de la Trinidad [vid. del mismo libro pág. 123]. Se conserva en la Colección de la Real Academia Española, RAE2947, fols. 50r-56r.

${ }^{43}$ Indicado por Rico, Predicación, pág. 15, al caracterizar el sermón vicentino.
} 
cumplimiento de los días festivos, olvido de la oración, abandono de la lectura de la ley y la enumeración podría seguir. Hay varias coplas que son exclusivamente listas de hechos pecaminosos y otras que, tras la descripción de ellos, presentan las buenas virtudes y acciones a cumplir. La copla más extensa del corpus (205 estrofas) y que, por tanto, más detalladamente describe los actos de pecado es Las malas costumbres. En ella se leen las siguientes estrofas sobre la falta de honradez en los negocios (est. 41-42):

$$
\begin{aligned}
& \text { Pensando va uno y otro } \\
& \text { quén le entraá en la mano: } \\
& \text { "iGuay del primero que encontro, } \\
& \text { aunque sea mi hermano!" } \\
& \text {-Buenos días, hạ Fum Fulano, } \\
& \text { ¿cómo estamos de ahabá?- } \\
& \text { (iSi le entra en la mano } \\
& \text { meterlo en la torbá!) }
\end{aligned}
$$

Combinar la tercera persona, las intromisiones del autor y el discurso directo para condenar el fraude da pie para introducir una cotidianidad que permite la escenificación y el uso de un lenguaje llano, que lleva a una mezcla de registros que ayuda a que los temas graves se acomoden a la sencillez del pueblo. Cátedra dice con respecto a los sermones que:

la convivencia de registros altos y bajos es algo puesto hoy fuera de duda y se admite muy generalmente la interferencia continua y hasta podría decirse que obligatoria en el mundo de la predicación popular y la culta $[. . .]^{46}$.

Díaz-Mas destaca al hablar de El pecado original:

la compatibilidad entre un asunto grave (nada más grave que el pecado original) y el tratamiento humorístico, en la forma como la serpiente tienta a Eva, el comentario de doble sentido de que "al marido - Adán - un figo le habían dado" [...] y la bobalicona reacción de Eva ante la ira divina, excusándose de su pecado porque "tú me feziste de una costilla tuerta" [... $]^{47}$

y añade que ello se encuentra también en el mester de clerecía y, especialmente, en Berceo.

44 entrar (alg.) en la mano (de otro): 'engañarle'.

45 ham: 'don, señor'; ahaba: lit. 'amor', el verso debe entenderse como 'iqué tal está?'; torḅá: 'saco'; Romero, Seis, págs. 81-82, interpreta estos dos versos finales como que "sj el otro se deja, lo va a meter en el saco [...], Io va a engañar". Asimismo señala que el que habla en los dos primeros versos de esta estrofa es el visitante (también comerciante que va a vender sus mercancías). Los dos últimos deben ser puestos en boca del coplero, los cuales son "dichos iróricamente [...], contrastando con la en apariencia amable actitud del comerciante."

46 Cátedra, Manuscrito, pág. 42.

${ }^{47}$ Díaz-Mas, "Poesfa", pág. 37. 
En el tratamiento que del tema de la muerte hacen es donde más dramática y violentamente quedan reflejados los "quatro clamores", que reclamaba el predicador medieval arriba citado, en el hacer de los copleros sefardíes. Las imágenes claras, duras y escabrosas con las que se describen el proceso y los efectos de morir - generalmente contrapuestas con esas que muestran los mejores lujos de la vida y la codicia del hombre y emparejadas con constantes apelaciones y preguntas a él ("para mientes d'ánde vienes / y tu fin polvo y tiera" 48 ; "que ¿qué viene de el cielo / que no recibe la tiera?" "49; "Cómo bušcaréx repośo, / alegría, gusto y goźo? / Su cabo es de cerar el ojo / y pudrirse en la tiera" ${ }^{50}$ ) - se convierten en el más eficaz instrumento para señalar la insignificancia del ser humano, el carácter destructor de la muerte y la inutilidad de lo terreno y, por lo tanto, el mejor medio para atemorizar a la conciencia pecadora para que cambie su conducta y, tras su arrepentimiento, consolarla al mostrarle los beneficios, no terrenales, de vivir bajo el dictado de Dios.

Por un lado, la vida es entendida como un camino de preparación para llegar con plena capacidad de gozar de la vida eterna en el momento del óbito, como dice la siguiente estrofa de Vanidad de las riquezas (est. 12):

$$
\begin{aligned}
& \text { La vida es un viaje } \\
& \text { por ganar avantaje; } \\
& \text { la muerte es un pasaje } \\
& \text { al mundo de la verdad. }
\end{aligned}
$$

por otro, la muerte se presenta en su papel democrático de igualadora social ${ }^{51}$, según se lee en Los extremos de la vida (est. 12):

Tanto grande como chico se meśuran con un pico: viejo, mozo, probe y rico, a todos cubre la tiera.

Pero, especialmente importantes, son esas alusiones que ponen énfasis en la pequeñez del hombre - la cual no es percibida cuando se peca, especialmente cuando se persiguen riquezas-, tanto en su paulatina destrucción física en vida, como cuenta Las edades del hombre (ests. 19-20, 23-24):

${ }^{48}$ Los extremos de la vida (vs. 2cd).

${ }_{49}$ Los extremos de la vida (vs. 10cd).

so Contra los soberbios (est. 16).

51 Topico presente en toda la literatura moral, como ejemplo para la tradición cristiana sirva La Danza de la Muerte, que también se recoge en los Proverbios [cito de Diaz-Mas y Mota, Proverbios, pág. 165]:

$$
\begin{aligned}
& \text { tienle gran miedo fuerte que le abantajará: } \\
& \text { no-1 miembra de la muerte que los igualará. }
\end{aligned}
$$


Cuando tiene los cincuenta tiene dolores sin cuenta: la vejez que le apreta y el gobierno de el hombre.

¿Cuálo mirará primero si él ya es un madero: servir al Dio verdadero o beneficio del hombre?

En setenta como loco todos lo toman en poco, lleno de flema y moco que se ataganta el hombre.

No queda más que el pelejo, se encoge como un conejo; dićen: "Muriera este viejo, ¿qué espera más este hombre?

como en su destino de pudrirse y quedarse solo y sin nada en la tierra tras la muerte, según revelan Los pesares del alma (ests. $28,31,40$ ):

Viéndomos bien vestidos de gavá somos en.volvidos, no metemos muestro sentido que todo queda en la tiera.

Toda la ropa que es querida, que de seda es tejida, del guśano es salida, los que comen al honbre en la tiera.

Y su tripa es partida y su mubre es salida y su came es comida del guśano de la tiera.

y La última jomada (ests. 12, 14-16):
Viene el aron y tamién los llenzos, todo quen lo oye se modre los bezos. Carne no le queda su haber lo deja sino más que gỉesos, una vez se va y sus bienes solta: otra veź no yolta ${ }^{52}$.

52 arón: 'féretro'. 


\begin{tabular}{|c|c|}
\hline $\begin{array}{l}\text { El telek muy viejo } \\
\text { le mete enriba } \\
\text { na mejor vestido } \\
\text { por saco y surtú } \\
\text { Agora se topa }\end{array}$ & $\begin{array}{l}\text { de la barba blanca } \\
\text { sábana muy blanca; } \\
\text { moda a la franca } \\
\text { y tamién un palto. } \\
\text { él de todo falto }{ }^{53} \text {. }\end{array}$ \\
\hline $\begin{array}{l}\text { El arón le atan } \\
\text { como que se fuye } \\
\text { meterán a él } \\
\text { quen y quen vendrá } \\
\text { como que lo llevan }\end{array}$ & $\begin{array}{l}\text { cuedra sobre cuedra } \\
\text { y sale afuera, } \\
\text { una buena piedra; } \\
\text { a tocar el palo } \\
\text { a un buen de balo }\end{array}$ \\
\hline $\begin{array}{l}\text { Ya se yola presto, } \\
\text { tiera ya le echan } \\
\text { el se topa estrecho } \\
\text { Cuando ya escapó } \\
\text { ba'avonot le viene }\end{array}$ & $\begin{array}{l}\text { pájaro sin alas; } \\
\text { a pueder de palas, } \\
\text { en lugar de salas. } \\
\text { el mal de el dever } \\
\text { al hibut haquéber }{ }^{55} \text {. }\end{array}$ \\
\hline
\end{tabular}

El poco valor del hombre, el acecho de la muerte y el arrepentimiento de los pecados —es frecuente en el poema admonitivo que se reserve una estrofa, o más, para la reflexión y contrición del pecador- son tópicos propios de la poesía penitencial judía, especialmente en la que se recita en los días penitenciales de yamim nora'im, los cuales están presentes en el Talmud y el Midrás. En varios pasajes de Proverbios morales se recogen:

${ }^{53}$ telek: 'bañero profesional'. Romero, Última, pág. 409 , explica los tres versos finales como "sthe aquí que (tc. na), con la mortaja, está mejor vestiđo que cuando usaba las prendas típicas de la moda occidental (a la franca), ya que aquélla le sirve a la vez de chaqueta (saco), gabán (surtí) y abrigo (paltó)"; menos probable nos parece entender vestido como sustantivo, es decir, "he aquí que éste es un vestido mejor que el de la moda occidental ..." En cualquier caso, el muerto se encuentra ahora despojado de todo cuanto poséáa, incluso de su vestimenta."

$\$ 4$ Romero, Última, págs. $409-410$, explica los versos a-b como "E] féretro queda atado y bien atado como para impedir que el muerto pueda huir de él"; el verso c, "Abundando en la misma idea de los vs. a-b, se anticipa el momento en que pondrán una lápida en su tumba, lápida que parece tener la misma finalidad de impedir que el muerto se escape"; los vs. d-e, "Se describe el momento del traslado de los restos al cementerio por mano o a hombros de parientes y amigos, quienes se tumarán en lievar las andas. En el v. $c$ se alude al uso de sillas de mano o palarquines habituales en Oriente para transportar a personajes."; balo: "baile'.

${ }_{55}$ Romero, Última, pág. 410, explica el verso a como "El metafórico vuelo puede ser el del descenso del ataúd a la hoya."; el verso c, "Es decir, el recinto donde ahora se encuentra es más reducido que el de las amplias salas de su mansión"; el verso d, "El dever del que se habrá liberado no parece que debamos relacionarlo con su homofono español deber, sino más bien con el tc. devir, devr 'época, era; ciclo; vuelta; circuito' y devre 'época, era; ciclo'. En la mística musulmana el término devtr se aplica al "cycle of existence passing out from the Divine Reality down through the Arc of Descent and then back into the godhead in the form of the Perfect Man" (Redhouse). Nehama recoge la palabra devre, que traduce 'changement de position, de place (en parlant d'un ballot, d'un sac, d'un colis)' [...]"; el verso e, "ba'avanot 'por los [sus] pecados, por desgracias' [...]; hibut haquéber lit, 'azotamiento en la tumba' [...] se refiere a los tormentos o azotes que según la creencia popular judía propinan los angeles encargados de tal tarea al cuerpo que acaba de ser enterrado." 


$\begin{array}{ll}\begin{array}{l}\text { E más que un mosquito } \\ \text { desque aquel esprito } \\ \text { que tu señor seria } \\ \text { comen de noch e día }\end{array} & \begin{array}{l}\text { el tu cuerpo non vale } \\ \text { que lo meçe d'él sale. [...] } \\ \text { mil vezes, e gusanos } \\ \text { su rostro e sus manos. }\end{array} \\ \begin{array}{l}\text { Mucho te marabillas, } \\ \text { porque todas las villas }\end{array} & \begin{array}{l}\text { tiéneste por menguado } \\ \text { non mandas del regnado. }\end{array} \\ \begin{array}{l}\text { ¿Eres rico? No.t fartas } \\ \text { con cobdiçia non catas }\end{array} & \begin{array}{l}\text { e tiéneste por pobre; } \\ \text { que lazras para otre. }\end{array} \\ \begin{array}{l}\text { E de tu algo, tocas } \\ \text { abrás, e varas pocas }\end{array} & \begin{array}{l}\text { para envolver tus güesos } \\ \text { de algunos lienços gruesos }\end{array} \\ \end{array}$

así como en Lamentación del alma ante la muerte, cuyo parecido de formulación con la copla sefardí Los extremos de la vida es especialmente significativo en la parte en la que se muestra el arrepentimiento del hombre antes de la muerte y los efectos destructores de ésta, en los que se enfatiza la soledad del bbito y la sencillez de la morada final:
Hora, ¿yo qué faré, o qué comidiré,
o qué quenta daré
Cuando se acerca la muerte
d'aquesta alma mía?
en nada no para miente.
Levar m'han sin tocado de todo se arepiente, todo le parece tiera.
a lo despoblado;
Él queda curero y güeso, dexar m'han en mi cado solo, sin compañía. en caśa, por entropezo, cinco tablas y un llenzo y cuatro picos de tiera.
Meter m'han n'angostura so de la tierra dura
Echado en lugar estrecho, hora, iqué amargura y quién lo sofriría! ${ }^{57}$ teśo, un palo derecho, la boca cerca del techo y por cubierta la tiera ${ }^{58}$.

Estos tópicos no provienen de fuentes ajenas a la tradición judía, ni en los poemas sefardíes ni en los hispanojudíos; sin embargo, creo que en ambas poesías sí existe un mayor gusto por el detalle macabro, un mayor deleite en la

${ }^{66}$ Diaz-Mas y Mota, Proverbios, pág. 174-175.

${ }^{57}$ Copio el texto de Cid, "Lamentación", pág. 754. Igual mensaje se reconoce en la literatura cristiana medieval, como se lee en la estrofa fina] del Libro de Alexandre [cito de Marcos Marín, Libro, pág. 455]:

${ }^{58}$ Ests. 16-18.

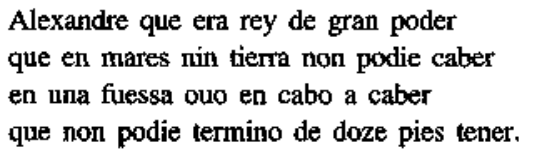


descripción de la degeneración humana que alcanza sus más altas cotas con la muerte de lo que se aprecia en la poesía de igual contenido escrita en hebreo en la península ${ }^{59}$ o en las traducciones sefardíes de poesías hebraicas destinadas a la liturgia de los días de penitencia ${ }^{60}$. Asimismo, dos coplas del corpus

${ }^{59}$ En los siguientes pasajes de José M." Millás Vallicrosa, La poesía sagrada hebraicoespañola, Madrid-Barcelona, CSIC, 1948, $2^{\mathrm{a}}$ ed., se observan los mismos tópicos arriba mencionados; sin embargo, no se percibe esa recreación en los detalles más sórdidos:

¿Cuál es la excelencia del hombre,

si su gloria desaparece como pájaro fugitivo?

Y ¿cómo podrá ensoberbecerse en su vida,

si de súbito le alcanza su ruina?

Entienda todo hombre inteligente $y$ discreto

que el término de toda cosa es la carcoma,

y que ciertamente dei polvo fuimos extraídos

y a él otra vez seremos idos. $[\ldots]$

(Tokehau; para la tarde del día de Kippur; pág. 238)

[...] 0 le sobrevienen đoiores, o inúndanle aguas tempestuosas.

$O$ le acaecen dolencias malas y persistentes.

Hasta que se considera una carga a sí mismo, y veneno de áspides encuentra en lugar de su miel.

Y cuando su dolor aumenta, su prestigio disminuye.

Y los mozalbetes se burlan de él y los jovenes le dominan.

Y se convierte en un peso para los salidos de sus propias entrañas, y todos sus amigos se hacen los desconocidos.

$\mathrm{Y}$ al legar su hora sale de sus estancias para la mansión de la muerte, y desde la sombra de sus cámaras a la sombra de la muerte.

Despójase de su recamado y de su púrpura y vístese gusano y polilla.

En el polvo se acuesta y toma a la raíz de la cual había sido cortado.

Un ser al cual llegan todas estas cosas, ¿cuándo encontrará momento para convertirse para lavar la mancha de su perversión?

El dia es corto, pero la tarea es larga. [...]

(Kéter Malkut, pág. 221)

* Igualmente, en Isaac Jerusalmi, Reuven Eliyahu Yisrael's Traduksyon Livre de las Poezias Ebraicas de Rosh ha-Shana i Kippur (5670) and the Six Selihoth of the 5682 edition, Cincinnati, Ladino Books, 1990:

Antes ke sea yevado al lugar de mis padres,

I sea puesto onde estan sus kadavres.

En la tyerra so konsiderado komo ajeno,

I mi verdadera morada sera en su seno. [...]

Komo ke bushke grandeza i lukso vano,

Kuando manyana sera mi kompanyero el guzano? [...]

El TYEMPO ke pasa, es el garante vero, Por asyertarme ke a la fin yo muero. 
admonitivo, Las edades del hombre y Los pesares del alma, presentan evidentes coincidencias con el Midrás hebreo medieval llamado Séder (o Meséjet) Yeŝrat Havalad ('Orden o Tratado de formación del nasciturus') ${ }^{\text {s1 }}$; sin embargo, en ellas, son originales esos pasajes en los que se detalla la degradación física del hombre (en Edades combinada con el texto midrásico):

Se le doblan sus enojos,

ya se le enublan los ojos, (vs. 18ab)

Cuando tiene los cincuenta

tiene dolores sin cuenta: (vs. 19ab)

En sesenta ya enpeza

a quitársele la fuerza;

ya tiene el pie en la fuesa, (vs. 21a-c)

Ni dinguno le viene a lado,

le llaman viejo pesgado,

el puerpo apasionado

que se desespera el hombre" 62 (est. 22)

En setenta como loco

todos lo toman en poco,

lleno de flema y moco

que se ataganta el hombre. (est. 23)

No queda más que el pelejo;

se encoge como un conejo; (vs. 24ab)

Los noventa no enmento

ni vo los meto en cuento

que ya se conta por muerto,

no se conta más por hombre. (est. 26)

Mi espirito retornara a akel ke me lo dyo,

I mi matyera a la tyerra, de onde se krio. [...]

(pág. 27)

Ombre! Pensa i preparate, i de tu nullidad seas konvensido,

Entyende byen lo ke sos tu, i de onde sos venido!

Ken te sostyene? Ken te asaventa? I kon kuala fuersa sos movido? [...]

(pág. 17)

${ }^{61}$ Elena Romero, "El Midrás Yesirat havalad y sus ecos en la literatura sefardí", Sefarad, 46. 1986, págs. 397-410; y La ley en la leyenda, Madrid, CSIC, 1989, el texto se recoge en págs. 318-323 [en adelante, Romero, Leyenda]. Las edades del hombre se identifica con la segunda parte del Midras, que detalla las diferentes etapas de la vida humana, y Los pesares del alma con las otras dos partes, la primera revela el proceso de formación del feto en ei útero de la madre y la tercera da cuenta de la muerte des hombre.

62 apasianado: 'con dolores'. 
hasta convertirse en nada tras la muerte (idea constante en Pesares en la admonición intercalada entre las dos partes inspiradas en la fuente hebrea):

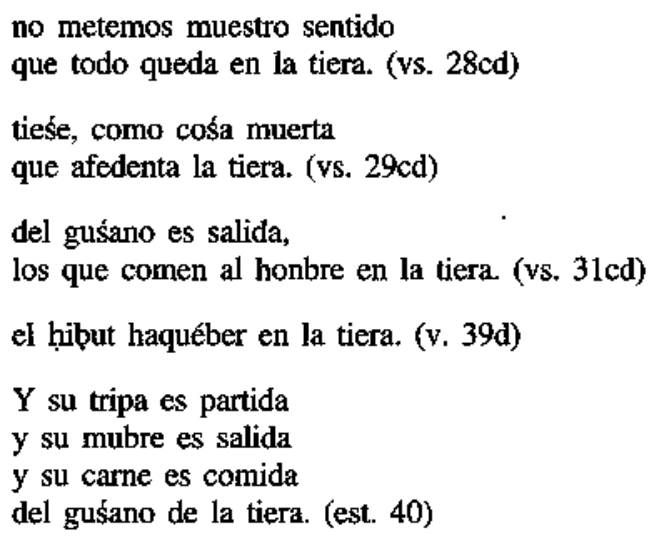

que no se encuentran en el Midráš:

[...] Camina con él el ángel desde la mañana hasta la tarde, mostrándole el lugar en donde está destinado a morir y el sitio en donde será enterrado. [...] En el séptimo tiempo se parece a un mono, pues se ha vuelto su figura diferente de la de todas las criaturas. Todo lo pregunta, come y bebe como un niño y juega como un crío, volviendo a la adolescencia en juicio pero no en lo otro. Incluso sus hijos y las gentes de su casa se burlan de él y lo insultan y lo aborrecen. Cuando dice algo le responden: "Dejadlo, que es al tiempo un niño y un viejo." Se parece a un mono en cuanto hace y dice, y hasta los niríos se burlan de él y lo convierten en un juguete; e incluso una golondrina le desvela de su sueño. [...] Por fin le llega su hora; viene entonces a su encuentro aquel mismo ángel [...] Para sacarte del mundo — le contesta-, que ya ha llegado tu tiempo de partir. $[. . .]^{63}$

En cambio, el tono de los poemas hispanojudíos y sefardíes sí parece estar en consonancia con los sermones, según se evidencia en los siguientes fragmentos de dos de ellos editados por Cátedra:

Ca quando el homne es vivo e sano, todos los días son por él; mas quando es a la muerte, dize el homne: - “ $¡ \mathrm{O}$, mesquino! ¿E qué será de mí? $\mathrm{Ca}$ agora avré de dexar todas quantas rriquezas he e en una mortaja pobre me meterán so la tierra”. $\mathrm{E}$ dirá: - “ $\mathrm{O} \mathrm{O}$, mesquino, que he trabajado quantos dampinos por las obras deste mundo; e era honrado en él, e agora meter me han deyuso de la tierra como despreçiado!". E cata cómo en aquel estado vernán todos los días contra ti, e dirás: - " $\mathrm{O} O$, mesquino, que tanto tienpo ha que di plazer e deletaçión a mi carne, comiendo e beviendo, e non ayunava,

${ }^{63}$ Romero, Leyenda, págs. 320-322. 
e agora comer me han gujanos! ‘Ay, mesquino yo, e non he confesado ogaño, e fize tantos males! ¿Qué será de mí?" 64 .

Dos males tiene aquella juuentud: el primero es que de la octra parte tiene por contraria la veged, armada de mill maneras de armas, donde el coraçón se angustia, la cabeça va tremiendo de vna parte a octra, enflaquece el spíritu, fiede el anélito, la faz se arruga, la statura se turba, obscurécense los ojos, tremen los [...] artejos, dentes putrescunt ('los dientes se tornan podridos'), las orejas ensordecen e breuemente las postrerías dél lo trahen a muerte $[. . .]^{65}$

Y es que la predicación popular se encargó de hacer llegar a todos el horror a la muerte tan característico del sentir cristiano medieval, el cual se va a convertir en tópico de toda la literatura didáctico-moralizante, como se ejemplifica en el Libro de miseria d'omne:

\begin{tabular}{|c|c|}
\hline $\begin{array}{l}\text { Quando es bivo el omne, } \\
\text { de piojos e lombrizes } \\
\text { muerto, cría los gujanos } \\
\text { que lo roen e lo comen, }\end{array}$ & $\begin{array}{l}\text { cría mota sin mesura } \\
\text { ca tal es la su natura; } \\
\text { con su mala podredura } \\
\text { dentro en su sepultura. }\end{array}$ \\
\hline $\begin{array}{l}\text { Quando es bibo el omne, } \\
\text { e desend quando es muerto, } \\
\text { ond non es cosa 'nel mundo } \\
\text { que tener muerto en casa }\end{array}$ & $\begin{array}{l}\text { da frutos de mal sabor, } \\
\text { podredura e fedor; } \\
\text { que omne quiera peor } \\
\text { maguer aya grand dolor. }\end{array}$ \\
\hline $\begin{array}{l}\text { E pues, ¿qué presta al omne } \\
\text { e los paños preciados } \\
\text { e aver grandes regnados } \\
\text { que la su carne mesquina }\end{array}$ & $\begin{array}{l}\text { riquezas e grand aver } \\
\text { e bien comer e beber } \\
\text { e emperador se[e]r, } \\
\text { así ha de podrecer? }\end{array}$ \\
\hline $\begin{array}{l}\text { Oy es el omne grand príncipe } \\
\text { está con [las] sus compañas } \\
\text { quando viene otro día, } \\
\text { métenlo en un sepulcro }\end{array}$ & $\begin{array}{l}\text { o reï apoderado, } \\
\text { en su palacio onrado; } \\
\text { los [que] él ovo criado } \\
\text { e déxanlo bien cerrado }\end{array}$ \\
\hline
\end{tabular}

${ }^{64}$ Cátedra, Sermón, pág. 329. Fragmento que pertenece a un sermón predicado por San Vícente Ferrer probablemente "el dorningo undécimo después de Pentecostés de 1411, 16 de agosto, en la Villa de Illescas" [vid. Cátedra, Sermon, pág. 323], con thema "Erat cotidie docens in templo" (Lc 19, 47). Se conserva en Ia Colección de la Real Academia, RAE2946, fols. 43r-50r.

${ }^{65}$ Cátedra, Sermones, pág. 95. Fragmento que es parte del sermón primero del Ms. 9433 de la Biblioteca Nacional de Madrid, fols. I-XIr, atribuido a Pedro Marín, del siglo Xv, el cual trata sobre la verdad de la muerte. En págs. 36-37, Cátedra indica que esta "terrorffica descripción de la degeneración por la vejez, [...] no es otra cosa que un romanceamiento de un fragmento bien conocido de De miseria humana conditionis de Inocencio III".

66 Connolly, Translation, pág. 174. 


\section{CONCLUSIÓN}

Las conclusiones a las que se lega a través de esta exposición ya han sido dadas por los estudiosos que se han acercado con anterioridad al tema de la relación entre la coplística sefardí y la literatura medieval peninsular. Por lo tanto, este trabajo sólo aporta nueva evidencia que apoya la buena dirección de tales investigaciones. La única diferencia entre este estudio y los precedentes es la aproximación hecha al tema, que en este caso se ha centrado en las características particulares de un grupo temático, el admonitivo, y no en las propias de las coplas como género (aunque algunas sean reconocibles como tales).

Así, por un lado, parece claro que existí un conocimiento y una coincidencia de prácticas y temas entre las dos clerecías del medievo español, la cristiana y la rabínica ${ }^{67}$, las cuales no se apartaban de las adoptadas en otras tradiciones literarias dentro de la corriente didáctico-moralizante que cubría Europa en este periodo ${ }^{68}$. Por otro, esa poesía rabínica se mantuvo en los años posteriores a la expulsión ${ }^{69}$ hasta que, en el siglo XVIII, en las comunidades sefardíes de oriente, resurgí de la mano de los copleros, quienes supieron dar vida a un genero original y castizo aprovechando técnicas y recursos de la tradición precedente.

${ }^{67}$ Díaz-Mas, "Clerecía", pág. 342, ya indicó que "esa clerecía rabínica debió de estar mucho más comunicada con la clerecía cristiana de lo que en principio pudiéramos suponer: lo prueban, por un lado, el manuscrito de los tres poemas medievales, que mezcla composiciones judías y cristianas; y, por otro, los rasgos "de clerecia" que notamos en algunos de los poemas judaicos (uso del heptasilabo, dialefa) y los rasgos judíos del propio Ay, therusalem".

${ }^{68}$ Francisco Rico, "La clerecía del mester", Hispanic Review, 53, 1985, págs. 1-23; Alvar y Gomez Moreno, Poesía.

${ }^{69}$ Díaz-Mas, "Clerecía", pág. 342, señala que esta "poesía no desapareció con la expulsión: siguieron conociéndola y transmitiéndola (tanto oralmente como por escrito) los criptojudíos de la península y los sefardíes expulsos; prueba de ello es el largo fragmento de los Proverbios morales recordado por el acusado de criptojudaísmo Ferrán Verde en 1492, la pervivencia de El pecado original en la tradición oral de Marruecos hasta el mismo siglo XX o la existencia de un manuscrito del siglo XVI con las Coplas de Yoçef. No sabemos si en ese largo período de varios siglos se compondrían nuevos poemas, pero es seguro que se transmitieron y recordaron varios de los medievales." 